

Journal of Hindu-Christian Studies

Volume 27

Article 9

November 2014

\title{
Angels and Gods: A (Radically) Orthodox Experiment
}

Daniel P. Sheridan

Saint Joseph's College of Maine

Follow this and additional works at: https://digitalcommons.butler.edu/jhcs

Part of the History of Religions of Eastern Origins Commons

\section{Recommended Citation}

Sheridan, Daniel P. (2014) "Angels and Gods: A (Radically) Orthodox Experiment," Journal of HinduChristian Studies: Vol. 27, Article 9.

Available at: https://doi.org/10.7825/2164-6279.1581

The Journal of Hindu-Christian Studies is a publication of the Society for Hindu-Christian Studies. The digital version is made available by Digital Commons @ Butler University. For questions about the Journal or the Society, please contact cbauman@butler.edu. For more information about Digital Commons @ Butler University, please contact digitalscholarship@butler.edu. 


\title{
Angels and Gods: \\ A (Radically) Orthodox Experiment
}

\author{
Daniel P. Sheridan \\ Saint Joseph's College of Maine
}

THIS is the third in a series of orthodox Catholic theological experiments that I am conducting within the theology of relationship of Catholic faith to other religions. Each experiment attempts to ask a positive, existential question of one of the world religions about the reality of one of their reality assertions. Catholic orthodox theologies have almost always answered these questions in the negative, but in my tentative and provisional judgment the negative answers may be unnecessary. To re-ask the questions using the "eyes of faith," the full weight and depth of orthodoxy must be brought to bear, not as a defensive posture that protects the faith, but instead as an exercise in confident Catholic inclusivity that will see how far it can go, in other words, to explore how inclusive Catholicity and orthodoxy can get.

In several ways, my theological experiments are related to the recent movement of "radical orthodoxy." ${ }^{2}$ This movement, largely among English Anglican and Catholic theologians, attempts to see how orthodox Christian theology, based on the creedal affirmations of the Councils, if indeed the affirmations are true, can help us to understand the dilemmas of modernity and post-modernity. Radical orthodoxy is experimental: "if the creedal affirmations are true, and not the fundamental assumptions of modernity and post-modernity, then what follows?" What follows is a radical reorientation through the eyes of faith, not only of the questions asked, but also of the answers given. Not only would our understanding of the contemporary situation be different, but how we would act and live in response might be profoundly different. In other words, if orthodoxy is true then the stance of Christian theology toward modernity and post-modernity should be quite different.

Daniel P. Sheridan, Ph.D. (Fordham University, 1976) is Professor of Theology at Saint Joseph's College in Maine. He is an engaged scholar at the intersection of Catholic systematic theology and the history of religions with special interest in Hindu theism, especially the Madhva tradition. He has published two books, The Advaitic Theism of the Bhagavata Purana [Motilal Banarsdass 1986] and Loving God: Krsna and Christ [Peeters 2007], and numerous articles in The Thomist, Anima, Journal of Religion, Horizons, Journal of Vaisnava Studies, Chicago Studies, Journal of Dharma, Current Issues in Catholic Higher Education, Studies in Formative Spirituality, Purana, Cross Currents, Journal of Religious Studies, Religious Traditions, Hindu-Christian Studies Bulletin, and Journal of Religious Pluralism. He is currently studying the work of Charles Taylor on secularity and writing a book on the Catholic theology of the diaconate. 
Another parallel between my experiments and "radical orthodoxy" is a common reaching out to and rediscovery for the theology of religions of the theistic metaphysics of Thomas Aquinas.

My first theological experiment asked, looking with the eyes of faith, whether there is any way Muhammad could actually be considered a prophet. ${ }^{3}$ I tentatively, and with considerable qualification, answered "yes". The second experiment asked whether there might actually be a Krishna who really exists, for example in and though the intentionality of the love of Mirabai for Krishna. ${ }^{4}$ I tentatively answered, "yes."

In this paper I want to consider Hindu gods and goddesses (devatā), but not God. Of course, we must be aware that the great Hindu theological traditions reach different conclusions on some important points relevant to this discussion. For example, the theological tradition of Madhva ${ }^{5}$ is very different from that of Samkara. ${ }^{6}$ Thus for the third experiment, I want to ask whether Hindu gods and goddesses might be affirmed as existent by considering them "spiritual substances." I will tentatively answer, "yes." Unfortunately, the more usual term for "spiritual substances," which are not also embodied, has been the jejune, worn out, term "angels." [In class I once mentioned "angels" as a theological category and the students burst into laughter.] I ask the question in the context of orthodox Catholic theology.

\section{Idolatry}

Catholic theology, systematic reflection on the believing of the Catholic community, is a wide ocean. The ocean has shallows, bays, currents, riptides, stagnant pools, and occasionally hurricanes. The deepest point in ocean is where it is most orthodox. The place in which I wish to situate a discussion of "gods and goddesses," and the preliminary subset of the same discussion, "idolatry," as categories in the Christian encounter with Hinduism is at the deepest point in the ocean, a point that encompasses both theology and philosophy, or a theology that is inclusive of philosophy. This discussion must have historical depth in the tradition, since gods and goddesses, and idolatry, are not major issues in contemporary Catholic theology and are not receiving much attention at present. My paper will have three sections: (1) a historical discussion of idolatry understood theologically, (2) a discussion of "intellectual substances," or angels, and (3) tentative conclusions.

I start with the topic of idolatry because the historical issues around idolatry have largely determined the negative judgment about the existence of spiritual substances postulated outside the Judeo-Christian tradition. ${ }^{7}$ In the first millennium of Christian thought, the negative judgment was that such substances were demonic, while in more recent centuries the judgment has been that they do not exist. However, a careful and nuanced review of the classic teaching about idolatry shows that its distinctions may set the stage for a more positive judgment.

Thus for Catholic theology, idolatry is defined as adoration directed to a creature, instead of to the God who was revealed personally at sinai and who is incarnate in Jesus Christ. Concretely, idolatry is usually applied to the adoration of material images that represent spiritual realities other than God. Thus the second prohibition of the Decalogue in Exodus 20:4: "You shall not make for yourself an idol, whether in the form of anything that is in heaven above, or that is on 
the earth beneath, or that is in the water underneath." For prophets like Hosea, idolatry is a form of adultery in relation to the covenant, which he compares to a marriage between God and the covenanted people of God. ${ }^{8}$ Idolatry would then be the supreme sin that betrays the covenantal relationship between God and this particular people.

After the first century, Christians, who suffered martyrdom because they refused to sacrifice to idols, similarly proclaimed the unique transcendence of God. Generally, they were not saying that idols were mere empty representations of that which lacked reality. To the contrary, the image represented a spiritual and personal reality that was not the unique and one transcendent God. Since the images and the realities they represented were not God, the adoration they received was an idolatry that was judged to be demonically inspired. Therefore, the spiritual realities so adored were demonic spiritual realities in revolt against the one unique transcendent God. ${ }^{9}$ Their existence was not denied.

For Jews, and at a later date for Muslims, it seemed that Christians engaged in idolatrous adoration when they worshipped Jesus, that is, Christians worshipped/adored someone who was not God as if he were God. However, in Catholic theology, when a Christian adores Jesus, the Son of God made flesh, it is the ultimate Personhood of the Son of God that receives the adoration given to the human being, Jesus of Nazareth, joined hypostatically to the Person of the Son of God. The incarnation of the Son of God does not cause loss to the transcendence of the divinity. The source of the divinity of the Son, the Father, does not become incarnate and thus remains absolutely transcendent, although the Father does beget the Son who does become incarnate. This is the reason down to the tenth century representations of God as the first person of the Trinity were not allowed, only representations of the humanity of Jesus, the incarnate Son.

Theology makes several further important conceptual distinctions. Adoration, under the denomination of the Greek term, latria, is the worship to be given to the transcendent God alone, or to wherever and/or to whomever, within whom that transcendent God has become incarnate. Thus adoration is properly given, without in any way losing transcendence, to the single reality of Jesus Christ, inseparably true God and true human being, or to the real presence of Jesus in the sacrament of the Eucharist. Dulia, a Greek term meaning service, is the veneration or homage given to saints, images of saints and relics, in emphatic contrast to the latria or adoration to be given to God alone. Hyperdulia designates the unique form of veneration to be given to Mary of Nazareth, the mother of Jesus of Nazareth.

On the one hand, Catholic theology shares with Judaism and Islam, an insight into the unique transcendence of God, and thus follows the prohibition of idolatry as misplaced adoration. On the other hand, theology affirms the unique incarnate presence of the transcendent God in the single person of Jesus Christ, who is thus a material reality uniquely worthy of the adoration due to the transcendent God alone. The distinction between this adoration, along with the reasons for this adoration, from the veneration of the saints and of Mary, and the reasons for that veneration, may provide us theological criteria to deal positively with Hindu gods and goddesses. 


\section{Intellectual Substances/Angels}

Although it is a much-neglected area of contemporary theology, a radically orthodox theology should include within its range a theological metaphysics of intellectual substances or incorporeal creatures, that is, angels. As Aquinas states:

"There must be some incorporeal creatures. For what is principally intended by God in creatures is good, and this consists in assimilation to God Himself. And the perfect assimilation of an effect to a cause is accomplished when the effect imitates the cause according to that whereby the cause produces the effect; as heat makes heat. Now God produces the creature by His intellect and will. Hence the perfection of the universe requires that there should be intellectual creatures. Now intelligence cannot be the action of a body, nor of any corporeal faculty; for every body is limited to here and now. Hence the perfection requires the existence of an incorporeal creature . . .But the very fact that intellect is above sense is a reasonable proof that there are some incorporeal things comprehensible by the intellect alone." ${ }^{10}$

This necessity for incorporeal creatures, and its key role in a theology of the purpose of the universe, was clearly seen by Pierre Rousselot, a key founder of Transcendental Thomism. The idea was taken up by Pierre Teilhard de Chardin, and may yet be incorporated into a theology of the universe. This necessity forms a profound basis for a radically orthodox dialogue with the great Hindu thinkers. Rousselot states:
"Let us try, following St. Thomas and his contemporaries, to think 'spiritual substance,' angel or soul, in its exquisite grandeur and its subtle purity. It is less in the material world than the material world is in it: continens magis quam contenta. It is more real because it has more being, and it is for that, too, that it is called 'substance."”11

This has been restated more cautiously by Karl Rahner in regard to angels: "As such they are at least in principle not inaccessible to natural empirical knowledge (which latter is not identical with scientific, quantitative experiment), and so they are not in themselves directly and necessarily a matter of revelation." ${ }^{12}$ By this he means that the original source of the content of the doctrine of angels was not divine revelation as such.

Angels exist. They are creatures who are aeviternal; they have a beginning but no end. As spiritual and personal, they are cosmic powers, principalities, and absolutely subject to a good and holy God, regardless of their goodness or wickedness. Like embodied human beings, they have a supernatural goal of grace in the direct beatific vision of God. In the continuity of God's spiritual creation from angels to humans, if God grants grace, that is, God's self-communication, to any, God grants it to all. They have decided freely for or against God. Their decision for or against God does not determine, but may influence, how humans work out their salvation or perdition. Veneration of angels is permitted. There is only one history of salvation for both angels and humans. Spiritual beings are a condition for the "supra-human and relatively personal character of evil in the world." ${ }^{13}$ They are innumerable. 
The Catechism of the Catholic Church states: "The existence of the spiritual, non-corporeal beings that sacred scripture usually calls 'angels' is a truth of faith. The witness of Scripture is as clear as the unanimity of Tradition." ${ }^{14}$ A delicate theological distinction needs to be made between what is "not necessarily a matter of revelation" and may still be "a truth of faith." Nevertheless, taken as true, there is nothing inherent in the idea of intellectual substances, angels, that precludes an existential judgment that the spiritual realities of Hinduism may be judged to exist.

\section{The Conditions for (Radically) Orthodox Experiments: Conclusions and Qualifications}

1. The previous presentation is theological, and not phenomenological or a posteriori. I have not discussed whether the "homage" rendered to God in "adoration/latria" is phenomenally, or phenomenologically, the same or different from the "homage" rendered to the saints, or to Mary, in "veneration/dulia/hyperdulia." This would be a very interesting area for empirical study. The results would possibly provide a methodological basis for comparing phenomenally "adoration" with bhakti or puja for example.

2. The categories are theological/ metaphysical, that is, radically orthodox. The disciplinary parameters of the history of religions/religious studies are quite different, although the categories of the history of religions/religious studies are to a great extent derived, and transmogrified, from the inventory of theological terms used in Catholic and Christian theology. Within inter-religious dialogue, and within the Hindu-Christian encounter, it is my judgment that a great deal of equivocation has taken place. I think that we have only begun to make careful distinctions. Many of our categories do not serve us well when we do not make these distinctions. The tenor of some of the reactions to the Vatican document, Dominus Iesus, reveals that a lot of work needs to be done to achieve mutual understanding. Part of mutual understanding is careful drawing of distinctions as the basis for the formation of truly illuminating categories for an on-going Catholic theology, an on-going history of religions/religious studies, an ongoing inter-religious dialogue, and an on-going Hindu-Christian encounter. ${ }^{15}$ These four "ongoings," and their need for illuminating categories, are related, but different. They need to be distinguished in order to be united.

3. Affirmations and negations are theologically different. They also may differ to the extent that they may be a priori or a posteriori. An affirmation that is a priori is essential to believing. A negation has a greater need to be a posteriori, based on a judgment that has attended to the evidence. Affirmations are at the heart of Christian believing, and thus at the heart of Catholic theology. Negations and prohibitions are seldom absolute, and are secondary to the affirmations. They have specific historical contexts. When the historical contexts change, what was previously negated or prohibited may also be subject to change. The key is whether the affirmation is maintained. The affirmation of light does not necessarily imply that an affirmation of darkness is called for.

4. There are several affirmations from the radically orthodox Catholic theology I have experimentally described here that may be useful for consideration within the HinduChristian encounter. This encounter should not 
take place solely on the basis of the history of religions/religious studies and its categories. At least from the Catholic side of the encounter, a radically orthodox theology may bring surprising insights to bear from its affirmations. Some of these might be:

a. the affirmation that spiritual beings, intellectual substances other than human, may really exist. The teaching about the existence of real spiritual substances [angels, demons, saints, the souls of the deceased, etc.] is presented within Catholic theology not solely as a conclusion of believing, but also one of reasoning, not one of theology alone, but of a theology joined to a certain philosophy that understands the role of intellect within reality, and within the universe. But it follows that, if real spiritual substances exist, they may be encountered, and thus perhaps Christians may really encounter the really existent Hindu gods and goddesses.

b. the affirmation that spiritual substances may exist in relationship to the material universe. Again in the words of Karl Rahner: "At the present time when people are only too ready to think it reasonable to suppose that because of the tremendous size of the cosmos there must be intelligent living beings outside the earth, men should not reject angels outright as unthinkable, provided that they are not regarded as mythological furnishings of a religious heaven, but primarily as 'principalities and powers' of the cosmos." 16 The Nicene-Constantinopolitan Creed affirms that God is the creator of all things visible and invisible. This is not just an affirmation about God, but also that the universe includes both the "visible and the invisible," that is, both material and spiritual realities in interaction. c. the affirmation that images/material objects within the cosmos ["idols" within a negative theological judgment] may really present or re-present real spiritual beings. Even if this affirmation was in the past a negative judgment that the images were "idols" since they represented what were thought to be demons, and indeed may have been demons, there is no reason why the affirmation could not be that they represent positive spiritual realities. The criteriology for such an affirmation on the basis of the affirmations of Christian believing remains to be established.

5. As a participant within the Catholic community of believers, it is possible for me to speculate or experiment as an individual theologian about certain issues that have never yet been raised or, if raised, not yet answered in the affirmative. For example, I have asked whether there is any set of premises/affirmations within Catholic believing and within Catholic theology under which it would be possible to answer in the affirmative that Muhammad is a prophet. Similarly, I have previously explored the question, both theologically and phenomenally, whether there really is a Krishna understood as God to be loved with whole heart, soul, and mind as Mirabai did. An affirmative answer based on the premises of a radically orthodox Catholic theology would open up exciting possibilities for the Hindu-Christian encounter. It may really be possible to affirm the Light without having to affirm that particular religious and spiritual realities are its negation, i.e., are Darkness. It may be really possible within an oceanic Catholic theology, based on the Creed's affirmations, for puja toward an image of Krishna to be affirmed positively as dulia/veneration, or even [more wildly] 
possible that it be affirmed as latria/adoration, and not as "idolatry" [understood here theologically, not as a category of the history of religions]. Finally, it may be really possible with an oceanic Catholic theology, at this point only tentatively and experimentally, to come to see the devatā as existent. These possibilities may arise only after careful distinctions within category formation have been worked out. The Hindu-Christian encounter would be enriched, and Catholic theology with the eyes of faith would see more than it presently sees.

\section{Notes}

${ }^{1}$ See Pierre Rousselot, The Eyes of Faith (New York: Fordham University Press, 1987).

2 See John Milbank; Catherine Pickstock; Graham Ward, ed., Radical Orthodoxy: A New Theology (New York: Routledge, 1999). See also Laurence P. Hemming, Radical Orthodoxy: A Catholic Enquiry (New York: Routledge, 1999) http://dx.doi.org/2027/mdp.39015050259053.

3 Daniel P. Sheridan, "Christian Faith's Judgment of Muhammad as a Prophet," The Journal of Religious Pluralism, V-VI (1995-96), p 127.

${ }^{4}$ Daniel P. Sheridan, "Faith in Jesus Christ in the Presence of Hindu Theism," in Joseph Prabhu, ed., The Intercultural Challenge of Raimon Panikkar (Maryknoll: Orbis Books, 1996), p. 145-161, http://dx.doi.org/2027/mdp.39015040739628.

See also, Daniel P. Sheridan, "Stations Keeping: Christ and Khrishna as Embodied," Cross Currents, XXXVIII (Fall 1988), 325-339.

${ }^{5}$ See Daniel P. Sheridan, "Direct Knowledge of God and Living Liberation in the Religious Thought of Madhva," in Andrew Fort and Patricia Mumme, ed., Living Liberation. (Albany: State University of New York Press, 1996), pp. 91-112.
6 See Francis X. Clooney, "Śaṃkara's Theological Realism: The Meaning and Usefulness of Gods (devatā) in the Uttara Mìmāmssā Sūtra Bhạsyya," in Bradley J. Malkovsky, ed., New Perspectives on Advaita Vedānta: Essays in Commenmoration of Professor Richard DeSmet, SJ (Leiden: Brill, 2000), pp. 30-50.

${ }^{7}$ For the Western theological tradition, a key figure was Saint Augustine, especially in the City of God. See Henry Bettenson, trans. Augustine. Concerning the City of God Against the Pagans (New York: Penguin, 1972), p. 87, http://dx.doi.org/2027/mdp.49015000758848:

"You must not regret the loss of those false and deceitful gods; abandon them in contempt and spring out to genuine liberty. They are not gods, but malignant fiends, and your eternal felicity is their eternal punishment."

8 See Hos 1.2: "for the land commits great whoredom by forsaking the Lord."

${ }^{9}$ See I Cor 10.20: "No, I imply that what pagans sacrifice, they sacrifice to demons and not to God."

${ }^{10}$ Thomas Aquinas, Summa Theologica I, question 50.

${ }^{11}$ Pierre Rousselot, Intelligence: Sense of Being, Faculty of God (Milwaukee: Marquette University Press, 1998), p. 29.

${ }^{12}$ Karl Rahner, "Angels," in Karl Rahner, ed., Encyclopedia of Theology: The Concise Sacramentum Mundi (New York: The Seabury Press, 1975), p. 5. http://dx.doi.org/2027/mdp.39015038075803

${ }^{13}$ Rahner, p. 13.

${ }^{14}$ The Catechism of the Catholic Church (Mahwah, NJ: Paulist Press, 1994), p. 85.

${ }^{15}$ See J. A. DiNoia, The Diversity of Religions: A Christian Perspective (Washington, DC: The Catholic University of America Press, 1992) http://dx.doi.org/2027/mdp.39015029187104. 
102 Daniel P. Sheridan

16 “Angels," p. 5.

\section{Bibliography}

Anderson, James F., trans. Saint Thomas Aquinas. Summa Contra Gentiles. Book Two: Creation. Notre Dame: University of Notre Dame Press, 1956.

Bettenson, Henry, trans. Augustine. Concerning the City of God Against the Pagans. New York: Penguin, 1972). http://dx.doi.org/2027/mdp.490150007588 48.

The Catechism of the Catholic Church. Mahwah, NJ: Paulist Press, 1994.

Clooney, Francis X. Theology After Vedanta: An Experiment in Comparative Theology. Albany: State University of New York Press, 1990.

. “Śamkara's Theological Realism: The Meaning and Usefulness of Gods (devatā) in the Uttara Mìmāmsāa Sūtra Bhāṣya," in Bradley J. Malkovsky, ed., New Perspectives on Advaita Vedānta: Essays in Commenmoration of Professor Richard DeSmet, SJ. Leiden: Brill, 2000.

Collins, James. The Thomistic Philosophy of Angels. Washington, DC: Catholic University of America Press, 1947.

Danielou, Jean. The Angels and Their Mission According to the Fathers of the Church. Westminster, Md.: The Newman Press, 1957. http://dx.doi.org/2027/inu.3000 0082 138193.

Davies, Brian. The Thought of Thomas Aquinas. Oxford: Clarendon Press, 1992. http://dx.doi.org/2027/mdp.390150222407 44

DiNoia, J. A. The Diversity of Religions: A Christian Perspective. Washington, DC: The Catholic University of America Press, 1992. http://dx.doi.org/2027/mdp.390150291871 04

Edwards, Sandra, trans. Quodlibetal Questions 1 and 2. Toronto: Pontifical Institute of Medieval Studies, 1983.

Foster, Kenelm, trans. St. Thomas Aquinas. Summa Theologiae Volume 9, Angels. New York: McGraw-Hill, 1963.

Harper, Ralph. On Presence: Variations and Reflections. Philadelphia: Trinity Press International, 1991. http://dx.doi.org /2027 /mdp.39015021977718

Hemming, Laurence P. Radical Orthodoxy: A Catholic Enquiry. New York : Routledge, 1999.

http://dx.doi.org/2027/mdp.390150502590 53

Keck, David. Angels and Angelology in the Middle Ages. New York: Oxford University Press, 1998.

Kretzmann, Norman. The Metaphysics of Creation. Oxford, Clarendon Press, 1999. http://dx.doi.org/10.1093/0199246548.001. 0001

The Metaphysics of Theism. Oxford: Clarendon Press, 1997. http://dx.doi.org/10.1093/019924653X.001. 0001

Milbank, John; Pickstock, Catherine; Ward, Graham, ed. Radical Orthodoxy : A New Theology. New York: Routledge, 1999.

Rahner, Rahner. “Angels,” in Karl Rahner, ed., Encyclopedia of Theology: The Concise Sacramentum Mundi. New York: The Seabury Press, 1975. http://dx.doi.org/2027 /mdp. 39015038075803

. "On Angels," in Theological Investigations. Volume XIX. Faith and Ministry. New York: 
Crossroad, 1983. http://dx.doi.org/2027/

mdp.39015008874250

. On the Theology of Death. New York: Herder and Herder, 1961. http://dx.doi.org/2027/inu.3200000747296 4

Rousselot, Pierre. The Intellectualism of Saint Thomas. New York: Sheed and Ward, 1935. http://dx.doi.org/2027/mdp.390150034892

29

. The Eyes of Faith. New York: Fordham University Press, 1987.

Schmaus, Michael. Dogma. God and Creation. The Foundations of Christology. Kansas City: Sheed and Ward, 1969.

Sheridan, Daniel P. "Christian Faith's Judgment of Muhammad as a Prophet," The Journal of Religious Pluralism, V-VI (1995-96), pp. 1-27.

. "Direct Knowledge of God and Living Liberation in the Religious Thought of Madhva," in Andrew Fort and Patricia Mumme, ed., Living Liberation. Albany: State University of New York Press, 1996.

. "Faith in Jesus Christ in the Presence of Hindu Theism," in Joseph Prabhu, ed., The Intercultural Challenge of Raimon Panikkar (Maryknoll: Orbis Books, 1996). http://dx.doi.org/2027/mdp.390150407396 28 . "Stations Keeping: Christ and Krishna as Embodied," Cross Currents, XXXVIII (Fall 1988), pp. 325-33. 